\title{
SERVICE-LEARNING TO REFLECT ON GENDER IN UNIVERSITIES AND SCHOOLS AND BOOST WOMEN'S PRESENCE IN ICT
}

\author{
Núria Vergés Bosch, Leon Freude, Clara Camps Calvet \\ Universitat de Barcelona (SPAIN)
}

\begin{abstract}
Service-Learning (APS), as a teaching methodology, is being increasingly implemented in our universities. However, there has been little research into its potential for a sociology committed to gender transformation and feminisms. In our courses on Sociology of Gender, we introduce our students to the main gender topics, as well as to feminist methodologies. Within these, gender and ICT, as well as feminist research and pedagogy, are covered. In this communication, we present an experience of Service-Learning around sociology and gender carried out in three consecutive courses. This experience was developed in the framework of the transversal project on Service-Learning at the University of Barcelona called Sharing ideas: the university goes to high school. Sharing Ideas is a Service-Learning project in which undergraduate and master's degree students from the University of Barcelona (UB) prepare lecture-workshops on interesting topics related to their studies and teach these in high schools which the university visits. Specifically, our experience consisted of teaching and accompanying our university students who study sociology of gender to carry out a lectureworkshop on gender and technology at secondary/high schools. Moreover, as an innovative element, we related our teaching to one of our research projects that aimed at improving the incorporation, retention and promotion of women in ICT. In the classrooms we then sought to work and reflect on gender socialization, the labour market with a gender perspective and, finally, to question the digital gender gap and to contribute to generating new technological vocations among girls. We based the evaluation of the project on a mixed-methods approach and a gender perspective. On the one hand, we took into account the evaluation surveys completed by the students; on the other hand, we analyzed qualitative data obtained through the observations and summaries of the experiences of the participating university students. Finally, from the design stage through to the evaluation of data we applied a gender perspective. This involved, on the one hand, considering the feminist research and agenda regarding gender and technology, as well as pedagogy and sociology. On the other hand, our experience specifically introduced gender contents and reflection in the APS project. Finally, this implied analysing our results and outcomes by considering gender, in relation to the contents as well as to the ascribed gender of our students and teachers. This allowed us to evaluate both the impact on the community as well as the impact on our students' learning process in a gender perspective. Apart from some limitations, the experience has been very satisfactory, both for the teachers and for the participating students of all levels and, in relation to gender as well, shows great potential for learning and transformation.
\end{abstract}

Keywords: Service-Learning, gender, sociology, IT inclusion.

\section{INTRODUCTION}

In this communication, we present the results of a Service-Learning teaching innovation project developed in the framework of Sociology. This consisted of training and accompanying university students to hold workshop conferences on the inclusion of women in information and communication technologies (ICT), a topic of interest to schools and society. This experience was part of a ServiceLearning (APS) project of the University of Barcelona, "Sharing Ideas" ([1], [2], [3]). We aimed to apply the most recent theoretical contributions, working in an interdisciplinary and inter-institutional manner, linking our research with our teaching and the return to the community. We will present here the theoretical debate first, then we will explain the project carried out and analyse the data, indicating some first results and our main conclusions in this regard.

Service-Learning is a teaching methodology that involves the "integration of course content and community service activities, with an emphasis on student's reflections" ([4]). It is a broad term that involves various educational experiences of students within the community, but requires that the students involved learn and, in turn, contribute to the world outside the classroom ([5]). As a method of university teaching, Service-Learning cannot be ascribed to specific disciplines, since it is present in all areas ([6]). Even so, many authors argue that Service-Learning results specially connected with 
sociology ([5], [6], [7]). There are many references to Mill's sociological imagination that facilitates Service-Learning ([5], [6], [7], [8], [9]) to a lesser extent it also refers to Paulo Freire ([8]), the Chicago school ([10],[6]) and John Dewey ([10]). Despite this background it was not until the 1980s ([4]) or the 1990s ([8]) that there was an emergency of Service-Learning in university education. From these experiences, a debate generated in the academic field that is still useful for planning, implementing and evaluating our Service-Learning project.

Most of the positive results of Service-Learning focus on the effects on students, especially their academic performance. Among academic performance ([5]) we highlight "student enthusiasm and participation" ([4]). As beneficial Service-Learning is applied and "engages students in discussions about the promise and limitations of public policy" ([11]). Service-Learning also facilitates a better understanding of complex sociological problems such as the structure-agency debate ([5], [9], [12]), increases empathy with others ([4], and helps to self-understanding and awareness ([8]). The constant dialogue with the other, mentoring and co-learning, allows the assessment of "various forms of expertise, from grounded and experiential, to practical and applied, to abstract and theoretical" ([9]). Feminist methodologies and pedagogies ([13], [14], [15]) share this approach. At a methodological level, the observation-action-analysis-reflection circle of Service-Learning is valued as a "powerful epistemological process" ([9]). Apart from academic performance, Service-Learning projects can also contribute to reducing stereotypes ([12]), as well as encouraging more involvement in civil society ([4], [5], [12]) and engaging social transformation ([4], [8], [15]). Finally, Service-Learning projects enable students to explore "careers inside non-profit organizations, social service agencies, and the public sector more general" ([8]).

The challenges related to Service-Learning are mainly related to the benefits for the community: the idea that it is a "win-win-win situation for the university, students and community" ([7]) is in question. If there are complaints from the community, they are addressed to "student's unreliability and lack of motivation and commitment" ([7]), lack of professionalism, work ethic, inability to take the initiative or unprofessional communication ([7]), as well as the lack of pedagogical tools ([4]. Students are often considered poorly prepared and poorly organized, which means a "draining of organizational resources" ([7]) for the organization. That is why the authors advocate a community perspective, which places the needs of the community at the center ([7]), while others emphasize the provision of pedagogical techniques as well as better theoretical training ([4]).

Other criticisms regarding Service-Learning point to "its emphasis on charity and volunteering, rather than citizenship and advocacy, and for the subsequent lack of attention to promoting social change" ([12]). It is also questioned that despite the aspiration of mutual learning Service-Learning privileges university knowledge and learning ([5], [9]). Authors also admit that it is difficult to create a mutual exchange relationship ([8]). Finally, reproductions of neoliberalism have been detected when implementing Service-Learning. In this regard some authors ([10]) alert us that: "As service-learning increasingly has become integrated into undergraduate education, it can all-too-easily morph into" McService ', what John Eby ( 1998) deems 'service bites, quick fix service, happy meal community service or service in box' "([10]), services that are not done with motivation for social transformation but to fill in the curriculum.

\section{METHODOLOGY}

The Service-Learning project carried out was developed within the framework of the broader project "Share ideas" of the University of Barcelona. This project offers to the public schools of Barcelona conference-workshop sessions that the university students plan and implement. Professors propose the title and the agenda of the sessions and the action is prepared within the framework of their subjects. We proposed a workshop with the title "Gender and technology: promoting new technological vocations" (Gèneres i tecnologies: Fomentant noves vocacions tecnològiques). We did so in the framework of the subjects Sociology of Gender (Degree of Sociology) and Welfare, Family and Gender (Master of Gender Studies) taking advantage of synergies with our research project "GENTALENT - Recruitment, retention and promotion of the talent of women in the ICT sector" and the gender and technology thematic block.

In our context, women are still a minority and excluded from ICT and our research and previous literature urge to better include them ([16], [17]). With this workshop, we sought to help to reflect around the gender and ICT relationship for both, university and school students. In this regard, we aimed at covering the following subtopics: to work and rethink the talent of women in technology; to understand the importance of including women in ICT; to show gender inequalities and injustices, but 
also ways to overcome and question them; to help to understand the structure-agency debate based on the problematization of preferences and sex based decisions. Finally, we aimed at disseminating scientific based results, as our results of the above-mentioned research project, and look for other and new ways to overcome some of the challenges involved, as well as we sought to allow dialogue among students. In this sense, we insisted on implementing interventions as workshops instead of just conferences or talks.

In total we have performed seven interventions over 3 consecutive academic courses, 2016/17, 2017/18 and 2018/19.

Figure 1. Summary of the workshops.

\begin{tabular}{|l|c|c|c|}
\hline & $2016 / 2017$ & $2017 / 2018$ & $2018 / 2019$ \\
\hline N. University Students & 3 & 5 & 5 \\
\hline Subject & $\begin{array}{l}\text { Sociology of Gender } \\
\text { (Degree) }\end{array}$ & $\begin{array}{l}\text { Sociology of Gender } \\
\text { (Degree) } \\
\text { Welfare, family and } \\
\text { Gender (Master) }\end{array}$ & $\begin{array}{l}\text { Sociology of Gender } \\
\text { (Degree) }\end{array}$ \\
\hline N. Workshops & 1 & 2 & 4 \\
\hline N. Schools & 1 & 2 & 1 \\
\hline N. School Students & 26 & $47+18$ & 100 \\
\hline
\end{tabular}

Source: Authors' elaboration

For the evaluation of the Service-Learning experience we considered the qualitative written selfassessment reports of our university students. In addition, and taking into account the community perspective, we have a quantitative assessment, with qualitative comments, made by teachers and school students immediately after the intervention, as well as the university subject marks. Additionally, we also consider the material generated in the sessions and in some cases other documentation that our students produced throughout implementing their experience. Through the whole process we aimed at wearing gender lens and therefore, take into account feminist pedagogy and research in the design of the experience, the analysis of data and the presentation of results ([13], [15]).

The self-assessment reports of our students help us to understand to what extent resulted in a positive experience concerning previous literature. This will be analyzed by paying special attention to elements such as: enthusiasm and motivation ([4]), limits on public policies ([11]), understanding of sociological problems ([5], [9], [12]), empathy ([4]), self-understanding ([8]), mentoring and co-learning, epistemological process ([9]), social activism / transformation ([5], [4], [12]), as well as professionalization ([12]) and gender ([15]). In addition, we can analyze to what extent we managed to overcome the challenges associated with Service-Learning, and pointed out in this introduction, such as the lack of professionalism and pedagogical techniques ([7]). The products generated in or from the session can also be key to understanding how the transmission and reception of complex sociological problems and the readjustment of ideas were articulated ([5], [9], [12]).

Figure 2: Assessment Materials.

\begin{tabular}{|l|c|c|c|}
\hline & $2016 / 2017$ & $2017 / 2018$ & $2018 / 2019$ \\
\hline Reports (University Students) & 1 & 5 & 5 \\
\hline Marks (University Professors) & 3 & 5 & 5 \\
\hline Surveys (teachers) & - & 2 & 1 \\
\hline Surveys (students) & 24 & 46 & 80 \\
\hline Others & $\begin{array}{c}\text { Powerpoint Workshop } \\
\text { Drawings }\end{array}$ & $\begin{array}{c}\text { Audiovisual and } \\
\text { workshop drawings }\end{array}$ & $\begin{array}{c}\text { Workshop } \\
\text { Drawings }\end{array}$ \\
\hline
\end{tabular}

Source: Author's Elaboration

Surveys distributed to participants and school teachers after the workshop allowed us to have an idea about how the project was received by the community. In this regard, we can find out if the conference responded to the needs of the community ([7]), since students were asked on their interest in the 
topic, the novelty of the content and the usefulness of the conference. We can also delve into sex/gender differences in their responses ([15]). Teachers were asked if the conference corresponded to the needs of the students, if it was adapted to the annual planning and if it was useful for the students. The evaluation of pedagogical tools ([4], [7]) was measured based on three questions answered by the respondents: Understanding the contents, Good content transmission and good way of explaining. The teaching staff also evaluates the transmission of the contents, the comprehensibility of the vocabulary and a motivating methodology. Regarding a dialogic environment and the creation of horizontal knowledge ([8]), participants assessed to what extent the dynamics were participatory, as well as the receptive attitude of the speakers. The teaching staff also indicated if participatory dynamics were carried out and if the doubts were resolved with flexibility. Apart from the global assessment that participants and teachers were asked for, teachers also assessed whether the information and management prior to the intervention was adequate. With all that, we also contrasted one of the main challenges behind Service-Learning experiences, thus the management work that generates Service-Learning for the community ([7]).

\section{RESULTS}

Both our university students and the participating school community indicate a high degree of satisfaction with the experience. All parties see the development of the workshop with enthusiasm and motivation - among school students and teacher, as well as among our students and professors. Students have come to a more complete understanding of multiple problems of sociology and gender studies - although they do not seem to have deepened much in the limits of public policies. In the reflections of our students, empathy appeared and so was confirmed by the school students. All activity shines through multiple learning in multiple directions. Especially for our students, a powerful learning process opportunity was generated. The activity and reflection itself initiated a process of selfunderstanding of our students that touches very personal elements as well as the will of social transformation or even their future professionalization.

Figure 3. Evaluation of the Experience. School Teachers and Students.

\begin{tabular}{|l|c|c|c|c|c|}
\hline & $22 / 12 / 2017$ & $M$ & 18/01/2018 & $M$ & $\begin{array}{c}29 / 10 / 2018 \\
+ \\
31 / 10 / 2018\end{array}$ \\
\hline Management was adequate & 10 & 10 & 7 & 5 & 9 \\
\hline Meets our needs & 9 & 9 & 8 & 6 & 8,5 \\
\hline Adjustment to our annual planning & 7 & 7 & 9,5 & 9 & 8,5 \\
\hline Transmission of new content & 10 & 10 & 8 & 6 & 7,5 \\
\hline Comprehensibility of Vocabulary & 10 & 10 & 9,5 & 9 & 9 \\
\hline Motivating methodologies & 10 & 10 & 8 & 6 & 7,5 \\
\hline Participatory dynamics & & & 9 & 8 & 8,5 \\
\hline Flexible resolution of doubts & 10 & 10 & 9 & 8 & 7,5 \\
\hline Workshop utility & 10 & 10 & 9 & 8 & 8 \\
\hline General evaluation & 9 & 9 & 8 & 6 & 8 \\
\hline
\end{tabular}

Source: Authors' Elaboration

In spite of that, the benefits were not only given to our university students, the planning and implementation of the workshop had a community vision. The quantitative and qualitative evaluation indicates that the workshop responds to the needs of the community and that it was achieved based on innovative pedagogical tools in a dialogic environment and the creation of horizontal knowledge. This was also confirmed by the evaluations of the teachers of the schools, which evaluate the usefulness of the conference and the comprehensibility of the vocabulary especially well.

Students also assessed the Service-Learning experience very positively - although worse than the teachers and with important differences within the group itself. We can highlight a very high degree of satisfaction with the receptive attitude of our university students. Likewise, we must recognize that the workshop utility and the learning of new content received - contrary to the evaluation of the teaching staff - gets worse scores. What is most striking is that people who did not want to either ascribe as 
men or as women (or who explicitly claimed to be non-binary and/or transgender) value almost all items worse than the rest. Disaggregating for the three years that we carried out the workshops we saw in the first two years that the same occurred among women. Female students evaluated the workshop experience worse than male students did. We might have several new hypothesis in this regard. In this sense, there is a need of specific research to illuminate its possible causes and impacts.

Figure 4. Evaluation of the Experience by Sex (School Students).

\begin{tabular}{|l|c|c|c|c|c|c|}
\hline & \multicolumn{2}{|c|}{ Men } & \multicolumn{2}{c|}{ Women } & \multicolumn{2}{c|}{ Non-binary } \\
\hline & $N$ & Average & N & Average & N & Average \\
\hline Interesting topic & 78 & 7,86 & 72 & 7,43 & 10 & 5,80 \\
\hline Comprehensive contents & 78 & 8,51 & 72 & 8,06 & 10 & 8,20 \\
\hline New contents & 78 & 7,23 & 72 & 7,00 & 10 & 5,40 \\
\hline Workshop utility & 77 & 7,23 & 72 & 7,07 & 10 & 6,30 \\
\hline Transmission of contents & 78 & 8,42 & 72 & 8,29 & 10 & 8,20 \\
\hline Participatory Dynamics & 77 & 8,22 & 72 & 7,93 & 10 & 6,50 \\
\hline Receptive attitude of speakers & 78 & 8,79 & 72 & 8,68 & 10 & 7,85 \\
\hline Good Explanation skills & 78 & 8,62 & 72 & 8,36 & 10 & 7,90 \\
\hline General evaluation & 78 & 8,35 & 72 & 8,19 & 10 & 6,95 \\
\hline
\end{tabular}

Source: Authors' Elaboration

In summary and taking into account all of our results, we believe that this experience of ServiceLearning was very positive for all parties involved. However, we still encountered some limitations. This include, on the one hand, the demand of our university students for better pedagogical advice. On the other, the lower scores of women and non-binary school students, which initially we aimed to influence the most. Finally, both teachers and students pointed to some design-organizational difficulties mostly related to duration and calendar.

\section{CONCLUSIONS}

As final remarks, we would like to highlight first, that our results show that Service-Learning is a useful tool to promote learning. Second, Service-Learning becomes an interesting tool to combine teaching and research, as well as a powerful vehicle for the dissemination of feminist research and, thereby, to contribute to gender transformations.

We obtained very good results among university students, considering both skills and the acquisition of knowledge. The other side of the equation, the community, also offers us very good results. Teachers value the experience very positively, as well as their students in many ways. However, we ought to emphasize that the community also has gender and this is important to be considered in our analysis. The community is not an homogenous whole, but differentiated according to sex-gender. The differences we observed demand further research and explanations.

In this regard, we introduce two open questions for future research. On the one hand, we ask ourselves about the community: Who is the community, just schools, students, teachers, together, beyond? How to take into account the needs of the students without subjugating them to the teachers' perspectives? On the other hand, we ask ourselves about feminist interventions in the classroom: How to foster new technological vocations without falling into essentialisms? How to avoid certain gender based resistances? How to make women visible without excluding non-binary genres?

We hope that successive evaluations and future research will allow us to answer these and new questions that will help us to advance in the knowledge and impacts of Service-Learning with gender perspective.

\section{ACKNOWLEDGEMENTS}

This article presents results of the teaching innovation project of the University of Barcelona Compartir idees" "(2015PID-UB/150). This article was also elaborated in the context of the INCASI Network, a 
European project that has received funding from the European Union's Horizon 2020 research and innovation programme under the Marie Skłodowska-Curie GA No 691004 and coordinated by Dr. Pedro López-Roldán. This article reflects only the author's view and the institutions are not responsible for any use that may be made of the information it contains.

\section{REFERENCES}

[1] Amat, A. F., \& Miravet, L. M. "El Aprendizaje Servicio en la Universidad: una estrategia en la formación de ciudadanía crítica". In Revista electrónica interuniversitaria de formación del profesorado, 13(4), pp. 69-77, 2010.

[2] Amat, C., Arias Sampériz, B., Asensio, J. A., Ballesteros Pérez, E., Costa Cuberta, M., i Chéliz, C. \& Fatjó-Vilas Mestre, M. "Compartir ideas, la universidad va al instituto. Análisis de la primera edición de un proyecto de aprendizaje servicio transversal a la Universidad de Barcelona". In Revista del CIDUI, 2016, 3, pp. 1-9, 2016.

[3] Morín Fraile, V., Sancho, R., Vázquez Archilla, M., Sarria Guerrero, J. A., Estrada Masllorens, J. M., Galimany Masclans, J. \& Maestre González, E., "Aprendiendo a educar para la salud a través del aprendizaje servicio. Compartir ideas, la universidad va al instituto". In Revista del CIDUI, 2016, 3, pp. 1-8, 2016.

[4] Hochschild Jr, T. R., Farley, M., \& Chee, V. "Incorporating sociology into community service classes". In Teaching Sociology, 42(2), pp. 105-118, 2014.

[5] Garoutte, L., "The Sociological Imagination and Community-based Learning: Using an Assetbased Approach". In Teaching Sociology, 46(2), pp. 148-159, 2018.

[6] Rondini, A. C., "Observations of critical consciousness development in the context of ServiceLearning". In Teaching Sociology, 43(2), pp. 137-145, 2015.

[7] Blouin, D. D., \& Perry, E. M., Whom does service learning really serve? Community-based organizations' perspectives on service learning. In Teaching Sociology, 37(2), pp. 120-135, 2009.

[8] Huisman, K. "Developing a sociological imagination by doing sociology: A methods-based servicelearning course on women and immigration". In Teaching sociology, 38(2), pp. 106-118, 2010.

[9] Marullo, S., Moayedi, R., \& Cooke, D., C. "Wright Mills's friendly critique of Service-Learning and an innovative response: Cross-institutional collaborations for community-based research". In Teaching Sociology, 37(1), pp. 61-75, 2009.

[10] Fletcher, E. H., \& Piemonte, N. M., "Navigating the Paradoxes of Neoliberalism: Quiet Subversion in Mentored Service-Learning for the Pre-Health Humanities". In Journal of Medical Humanities, 38(4), pp. 397-407, 2017.

[11] Rooks, D., \& Winkler, C., Learning interdisciplinarity: Service learning and the promise of interdisciplinary teaching. In Teaching Sociology, 40(1), pp. 2-20, 2012.

[12] Mobley, C., "Breaking ground: Engaging undergraduates in social change through service learning". In Teaching Sociology, 35(2), pp. 125-137, 2007.

[13] Luxán Serrano, M., \& Biglia, B. "Pedagogía cyberfeminísta: Entre utopía y realidades". Teoría de la Educación. In Educación y Cultura en la Sociedad de la Información, 12(2), pp.149-183,2011.

[14] Martínez Martín, I. "Construcción de una pedagogía feminista para una ciudadanía transformadora y contra-hegemónica". In Foro de Educación, (20), pp. 129-151, 2016.

[15] Biglia, B., \& Vergés Bosch, N., "Cuestionando la perspectiva de género en la investigación". REIRE. In Revista d'Innovació i Recerca en Educació, 2016, vol. 9, num. 2, pp. 12-29, 2016.

[16] González Ramos, A. M., Vergés Bosch, N., \& García, J. S. M. "Women in the technology labour market”. In Revista Española de Investigaciones Sociológicas (REIS), 159(159), 73-89, 2017.

[17] Vergés Bosch, N. "De la exclusión a la autoinclusión de las mujeres en las TIC. Motivaciones, posibilitadores y mecanismos de autoinclusión". In Athenea digital, 12(3), 129-150, 2012. 